\title{
KRISIS KARAKTER DALAM PERSPEKTIF TEORI STRUKTURAL FUNGSIONAL
}

\author{
Purnomo Sidi
}

SMP Negeri 3 Leksono Wonosobo

\begin{abstract}
Abstrak
Karakter adalah nilai-nilai yang harus dimiliki suatu bangsa untuk bisa eksis dala persaingan global. Struktur yang ada dalam masyarakat punya peranan dan tugas untuk menjaga nilai dan norma agar dapat menjadi pedoman masyarakat dalam bertindak. Krisis karakter yang terjadi di Indonesia adalah cermin dari kegagalan struktur sosial yang ada dalam menjalankan peran dan fungsinya. Mengembalikan fungsi struktur masyarakat adalah jawaban untuk menciptakan stabilitas dan keteraturan kehidupan masyarakat, sehingga dapat menghindarkan diri dari krisis karakter.
\end{abstract}

Kata kunci: krisis karakter, nilai dan norma, stuktural fungsional

\section{THE CRISIS OF CHARACTERS IN THE PERSPECTIVE OF STRUCTURAL FUNCTIONAL THEORY}

Purnomo Sidi

SMP Negeri 3 Leksono Wonosobo

\begin{abstract}
Characters are the values that must be possessed by the nation to exist in the global competition. The social structure in the society holds an important role and function to keep these values and norms in place to guide the society. The crisis of caracters occuring in Indonesia is the reflection of the social structure failure in implementing its role and function. Re-establishing the role and function is the answer to creat stability and regularity of society life, so that character crisis does not happen.
\end{abstract}

Keywords: character crisis, values and norm, social stucture 


\section{PENDAHULUAN}

Karakter suatu bangsa sangat penting untuk menentukan keberlangsungan hidup suatu bangsa tersebut. Bangsa dengan karakter kuat akan mampu eksis dan bersaing dalam percaturan dunia global. Sebaliknya bangsa yang mengalami krisis karakter akan tergilas oleh perubahan akhirnya menjadi banga pecundang dalam persaingan global. Negara dan masyarakat adalah sebuah organisasi fungsional yang berfungsi menjamin masyarakat hidup dalam keteraturan dan keselarasan. Struktur yang terbentuk dalam negara dan masyarakat harus bisa menjalankan fungsinya masing-masing agar terjadi keharmonisan dan stabilitas dalam kehidupan masyarakat. Karakter suatu bangsa akan kuat apabila apabila masing masing lembaga yang ada pada masyarakat baik itu negara, keluarga, lembaga pendidikan, lembaga pers ataupun struktur masyarakat yang lain dapat menjalankan fungsinya dalam menjaga nilai dan norma dan mampu mengendalikan perilaku anggotanya agar bertindak sesuai dengan nilai dan norma yang ada di masyarakat.

Negara akan gagal menjalankan fungsinya apabila dalam proses penyelanggaraan negara khususnya oleh aparatur birokrasi dipenuhi dengan praktik-praktik kotor seperti korupsi, nepotisme, pungli dan tindakan melawan hukum lainya yang umumnya demi kepentingan pribadi atau golongan. Indonesia sebagai negara besar disinyalir belum mampu menjalankan fungsinya sebagai negara yang mampu menjamin kesejahteraan warganya. Krisis multidimensi adalah kata yang tepat untuk menggambarkan keadaan Negara Indonesia pada beberapa tahun yang silam dan keadaan itu berlangsung hingga sekarang. Dimulai dengan krisis moneter pada sekitar tahun 1997, krisis akhlak, krisis kepercayaan diri, dan krisis moral terus melanda bangsa Indonesia. Kasus korupsi merupakan penyakit birokrasi yang telah mengakar dari tingkat pusat sampai dengan daerah. Mental korup telah menghinggapi hampir semua aparat birokrasi. Uang, materi, jabatan, dan kekuasaan mengabaikan, melupakan, bahkan mematikan moralitas.

Lingkungan masyarakat yang aman dan nyaman dirasakan semakin langka di masyarakat kita. Kasus pencurian, perampokan, perkosaan bahkan pembunuhan semakin sering dijumpai dalam masyarakat. Banyak- nya perjudian, minum-minuman keras menjadikan lingkungan tempat tinggal menjadi tempat yang tidak aman untuk pendidikan anak agar tumbuh kembang menjadi pribadi yang baik. Banyaknya kasus penculikan anak, perkosaan di tempat umum menjadikan ruang publik menjadi tempat yang berbahaya bagi anak-anak dan perempuan.

Keluarga sebagai peletak dasar pertama dan utama dari sistem nilai dan norma pada kehidupan modern sering kali bergeser peranannya disebabkan orang tua lebih sibuk bekerja karena tuntutan hidup yang makin tinggi, sehingga seringkali mengabaikan fungsi lainya. Banyak kaum ibu atas nama emansipasi, merintis menjadi wanita karier yang super sibuk sehingga tidak punya waktu untuk mendidik anak-anak mereka atau memberi kenyamanan bagi para suami mereka. Kurangnya kasih sayang dan kenyamanan dalam keluarga sehingga banyak anak yang melarikan diri dari keluarga dan terjebak dalam pergaulan bebas, tawuran, mengonsumsi rokok, minuman keras, dan narkoba. Tidak sedikit jumlah tindak kriminalitas yang dilakukan oleh remaja, seperti pengompasan, anarkisme ala geng motor, dan tindak kekerasan di antara geng anak perempuan.

Kejujuran juga dirasakan mulai melemah dalam praktik pendidikan di Indonesia. Kasus bertindak curang baik berupa menyontek, mencontoh pekerjaan teman seolaholeh merupakan pekerjaan sehari-hari. Praktik kecurangan yang dilakukan para pendidik dalam Ujian Nasional, markup nilai demi mengejar kelulusan selalu terjadi setiap tahun. Di kalangan perguruan tinggi tidak kalah memprihatinkan fenomena menyontek ujian dan tugas di kalangan mahasiswa, plagiarisme dalam karya ilmiah bahkan jual beli ijazah dari mahasiswa tingkat sarjana sampai dengan doktoral marak terjadi. Mengapa pendidikan belum mampu mengubah perilaku warga bangsa menjadi lebih baik?. Kasus PAK palsu yang melibatkan beberapa oknum guru, bukti lain bahwa dunia pendidikan telah kehilangan kejujuran yang seharusnya hal itu diajarkan pada anak didiknya.

Menurut UU No 40 tahun 1999 tentang Pers, pada Pasal 3 menyebutkan bahwa Pers nasional mempunyai fungsi sebagai media informasi, pendidikan, hiburan, dan kontrol sosial. Sebagai kontrol sosial pers diharapkan mampu memberikan berita yang kritis dan 
berimbang dalam rangka membuka komunikasi dengan publik untuk mengontrol adannya penyimpangan dalam masyarakat. Kebebasan pers yang tanpa kendali membuat peran media massa sebagai agen perubahan yang mengedukasi masyarakat terhadap, fakta, peristiwa, pengetahuan baru menjadi paradoks ketika tampilan yang disajikan justru lebih dominan berita negatif seperti; korupsi, pembunuhan, perkosaan, perselingkuhan artis atau pejabat pemerintah. Judi online, cybersex, atau tayangan yang berbau pornografi merupakan produk media massa yang bisa mengikis karakter masyarakat. Dengan konten pemberitaan negatif dan tidak berimbang media massa justru menciptakan kontradiktif, mendorong adanya penyimpangan dalam masyarakat yang bermuara pada krisis karakter bangsa.

Berbagai macam bentuk kasus yang telah penulis uraikan dimuka merupakan sebagian bukti bahwa krisis karakter telah akut melanda Bangsa Indonesia. Krisis karakter tersebut disinyalir karena lembaga dan struktur yang ada dalam negara dan masyarakat gagal menjalankan fungsinya dengan baik. Sehingga kendali yang harusnya dapat diperankan oleh struktur tersebut tidak dapat berjalan sebagaimana mestinya. Berdasarkan uraian masalah pada makalah ini penulis ingin memfokuskan pembahasan pada: (1) Tinjauan tentang krisis karakter; (2) Tinjauan tentang teori struktural fungsional; (3) Krisis karakter dalam perspektif teori struktural fungsional; (4) Upaya solusi dari krisis karakter dalam perspektif teori struktural fungsional.

\section{PEMBAHASAN}

\section{Tinjauan tentang Krisis Karakter}

Menurut kamus bahasa Indonesia kata "krisis" berarti keadaan yang berbahaya, atau genting. Sedangkan karakter adalah sesuatu yang ada dalam pikiran yang diwujudkan secara konsisten dalam tindakan sehari-hari. Seperti dikatakan oleh Helen G. Douglas, (Samani, 2012, p.41) Character isn't inherited. One builds its daily by the way one thinks and act, tought by thought, action by cotion. Hal ini diperkuat oleh Muchlas Samani (2012, p.43), yang mengatakan bahwa: karakter dapat dimaknai sebagai nilai dasar yang membangun pribadi seseorang, ter-bentuk baik karena pengaruh hereditas maupun pengaruh lingkungan, yang membe-dakannya dengan orang lain serta diwujudkan dalam sikap dan perilakunya sehari-hari. Lebih eksplisit Darmiyati Zuhdi (2012, p.15), mengataakan bahwa karakter tesusun atas ciriciri yang akan memandu seseorang melakukan hal-hal yang benar atau tidak akan melakukan hal-hal yang tidak benar.

Dari pengertian kedua istilah krisis dan karakter, maka dapat dipahami yang dimaksud dengan krisis karakter adalah hilangnya nilainilai/norma yang seharusnya dipegang teguh dalam kehidupan sehari-hari sehingga perilakunya menyimpang dari nilai-nilai yang ada dalam masyarakat. Krisis karakter merupakan persoalan serius, karena mengancap sendisendi kehidupan bermasyarakat dan berbangsa sehingga menyebabkan tumbuh menjadi bangsa yang lemah, bangsa yang tertindas oleh kemajuan jaman.

Gede Raka (Dwiningrum, 2012, pp.106107) mengidentifikasi beberapa penyebab yang memicu krisis karakter yang terus berkelanjutan, yaitu:

1. Terlena oleh sumber daya alam yang melimpah

Persepsi bahwa Indonesia kaya dengan sumbr daya alam yang melimpah justru akan menjadi malapetaka ketika tidak ada invensi kecerdasan sumber daya manusia, maka sumber daya alam tersebut tetap bernilai rendah.

2. Pembangunan ekonomi yang terlalu tertumpu pada modal fisik

Pembangun di Indonesia mulai era orde lama sampai dengan orde reformasi terlalu tertumpu pada modal fisik. Pembangunan modal nirwujud/maya seperti kecerdasan bangsa, pembangunan karakter, yang justru menjadi tumpuan ekonomi bangsa lain justru terabaikan.

3. Surutnya idealisme, berkembangnya pragmatism "overdoses"

Idealisme dianggap tidak penting, kejujuran dianggap penganggu pembangunan, sehingga masyarakat terjebak dalam pola pikir pragmatis yang overdoses, dan terjebak pula dalam sikap dan perilaku menghalalkan segala cara agar tujuan tercapai.

4. Kurang berhasil belajar dari pengalaman bangsa sendiri.

Kemerdekaan bangsa yang diperjuangkan para pahlawan dengan kekuatan senjata dan berubah dengan kekuatan modal maya harusnya menjadi catatan bahwa 
keberhasilan memerlukan pengorbanan besar memerlukan pemikiran besar. Hal ini yang tampaknya belum menginternalisasi dalam bangsa Indonesia.

Sedangkan menurut Lickona, sebuah bangsa sedang menuju jurang kehancuran jika memiliki sepuluh tanda-tanda seperti; (1) meningkatnya kekerasan di kalangan remaja; (2) membudayanya ketidakjujuran; (3) sikap fanatik terhadap kelompok/peer group; (4) rendahnya rasa hormat kepada orang tua dan guru; (5) semakin kaburnya moral baik dan buruk; (6) penggunaan bahasa yang memburuk; (7) meningkatnya perilaku merusak diri seperti, penggunaan narkoba, alkohol, dan seks bebas; (8) rendahnya rasa tanggung jawab sebagai individu dan sebagai warga negara; (9) menurunnya etos kerja, dan; (10) adanya saling curiga dan kurangnya kepedulian diantara sesama (Wibowo, 2012, p.16).

Ciri-ciri seperti disebutkan di atas dalam skala tertentu banyak kita jumpai dalam kehidupan masyarakat kita. Hal ini dapat disimpulkan bahwa telah terjadi krisis karakter hampir dalam semua lapangan kehidupan dalam berbagai jenjang usia. Krisis karakter dapat dipengaruhi oleh faktor individu maupun adanya pengaruh dari struktur sosial yang ada dalam masyarakat. Secara umum struktur sosial yang ada dalam masyarakat secara fungsional mampu mempengaruhi karakter individu, jadi peran struktur sosial sangat penting untuk mencegah dan mengurangi adanya krisis karakter dalam masyarakat.

\section{Tinjauan tentang Teori Struktural Fungsional}

Menurut teori struktural fungsional seperti yang dikemukakan Parsons bahwa masyarakat akan berada dalam kedaaan harmonis dan seimbang bila institusi/atau lembagalembaga yang ada pada masyarakat dan negara mampu menjaga stabilitas pada masyarakat tersebut. Struktur masyarakat yang dapat menjalankan fungsinya dengan baik dengan tetap menjaga nilai dan norma yang dijunjung tinggi oleh masyarakat maka hal ini akan menciptakan stabilitas pada masyarakat itu sendiri (Craib, 1986, p.58).

Teori struktural fungsional Talcot Parsons dimulai dengan empat fungsi penting untuk semua sistim "tindakan" yang disebut dengan skema AGIL. Melalui AGIL ini kemudian dikembangkan pemikiran mengenai struktur dan sistem. Menurut Parson fungsi adalah kumpulan kegiatan yang ditujukan ke arah pemenuhan kebutuhan tertentu atau kebutuhan sistem. Menurut Parson agar dapat bertahan sebuah sistem harus terdiri dari 4 fungsi yaitu :

1. Adaptation (adaptasi).

Sebuah sistem harus menanggulangi situasi eksternal yang gawat. Sistim harus menyesuaikan diri dengan lingkungan dan menyesuaikan lingkungan itu dengan kebutuhannya.

2. Goal attainment (pencapaian tujuan).

Sebuah sistem mendefinisikan dan mencapai tujuan utamanya.

3. Integration (integrasi).

Sebuah sistim harus mengatur antar hubungan bagian-bagian yang menjadi komponennya. Sistem juga harus mengelola antar hubungan ketiga fungsi penting lainnya (A, G, L). Masyarakat harus mengatur hubungan di antara komponenkomponennya supaya dia bisa berfungsi secara maksimal.

4. Latency (pemeliharaan pola)

Sebuah sistem harus memperlengkapi, memelihara, dan memperbaiki, baik motivasi individu maupun pola-pola kultural yang menciptakan dan menopang motivasi (Ritzer \& Douglas, 2005, p.121).

Menurut Parsons sebuah sistem sosial harus memiliki persyaratan-persyaratan yaitu ; Pertama, sistem sosial harus terstruktur (ditata) sedemikian rupa sehingga bisa beroperasi dalam hubungan yang harmonis dengan sistem lainya. Kedua, untuk menjaga kelangsungan hidupnya, sistem sosial harus mendapat dukungan yang diperlukan dari sistem yang lain. Ketiga, sistem sosial harus mampu memenuhi kebutuhan para aktornya dalam proporsi yang signifikan. Keempat, sistem harus mampu melahirkan partisipasi yang memadai dari anggotanya. Kelima, sistem sosial harus mampu mengendalikan perilaku yang berpotensi menganggu. $\mathrm{Ke}$ enam, bila konflik akan menimbulkan kekacauan maka itu harus dikendalikan. Ketujuh, untuk kelangsungan hidupnya, sistem sosial memerlukan bahasa (Ritzer \& Douglas, 2005, p.125).

Tokoh dengan pandangan penting dalam teori stuktural fungsional antara lain adalah Robert K Merton yang lebih menyukai 
teori-teori yang sifatnya terbatas dalam teori tingkat menengah. Salah satu sumbangan terpenting Merton adalah analisisnya mengenai hubungan antara kultur, struktural, dan anomie. Merton mendefinisikan kultur sebagai seperangkat hubungan sosial yang terorganisir, yang menentukan perilaku bersama anggota masyarakat atau anggota kelompoknya. Struktur sosial adalah seperangkat hubungan sosial yang terorganisir, yang dengan berbagai cara melibatkan anggota masyarakat atau kelompok di dalamnya (Anomie terjadi bila ada keterputusan hubungan antarnorma kultural dan tujuan dengan kapasitas yang terstruktur secara sosial dari anggota kelompok untuk bertindak sesuai dengan nilai kultural. Artinya karena posisi mereka dalam struktur sosial masyarakat, beberapa orang tak mampu bertindak sesuai dengan nilai normatif (Ritzer \& Douglas, 2005, p.142). Anomi terjadi ketika terdapat disfungsi akut antara norma-norma dan tujuan kultural yang terstruktur secara sosial dengan kemampuan anggota untuk bertindak menurut norma dan tujuan tersebut.

Masyarakat sebagai suatu sistem diatur oleh nilai-nilai dan norma-norma yang mapan. Suatu masyarakat yang bisa menjalankan fungsinya dengan baik, maka secara fungsional masyarakat tersebut telah mampu menjaga nilai dan norma agar kehidupan masyarakat tersebut dapat berjalan selaras dan harmonis. Konflik dalam suatu sistem masyarakat struktur fungsional yang teratur akan mampu teratasi dengan sendirinya, karena sistem selalu akan membawa pada keteraturan. Tetapi pada masyarakat yang secara struktural fungsional tidak mampu menjalan- kan perananya maka akan terjadi gesekan, konflik yang akan berujung pada krisis karakter dalam masyarakat.

Menurut Merton perilaku menyimpang disebabkan oleh ketidakbertautan antara nilai kultural dan cara-cara struktur sosial mencapai nilai kultural itu. Penyimpangan berarti adanya konsekuensi disfungsional dalam kesenjangan antara kebudayaan dan struktur yang mengarah pada penyimpangan dalam masyarakat (Ritzer \& Douglas, 205, p.143). Lebih lanjut Merton mengatakan bahwa perilaku individu sangat dipengaruhi oleh struktur sosialnya, menurutnya penyimpangan akan terjadi bila fungsi kontrol dari lembaga tersebut tidak ada (Poloma, 2007, p.33).

\section{Krisis Karakter dalam Perspektif Teori Struktural Fungsional}

Krisis karakter yang melanda hampir semua bidang kehidupan bermasyarakat di Indonesia adalah karena adanya kegagalan atau disfungsi lembaga-lembaga negara dan juga struktur sosial yang ada dalam masyarakat. Ketidakberdayaan lembaga dan struktur masyarakat dalam pengendalian sosial pada umumnya karena adanya penyimpangan oleh sebagian besar dari penyelenggara negara atau oleh sebagian besar pemimpin dan anggota masyarakat tersebut. Stuktur masyarakat tidak lagi mampu menjalankan fungsinya bila sebagian besar anggotanya melakukan penyimpangan nilai dan norma yang dianut. Gambaran penyimpangan akan nilai dan norma sebagai indikator krisis karakter disajikan pada Tabel 1.

Tabel 1. Kasus Korupsi di Kementerian dan Lembaga Negara

\begin{tabular}{lll}
\hline $\begin{array}{l}\text { Kementerian/Lembaga } \\
\text { Negara }\end{array}$ & Kerugian Negara & Belum ditindaklanjuti \\
\hline 1. Kejagung & Rp 5,43 triliun (473 temuan) & Rp 5,41 triliun (427 temuan) \\
2. Kemenkeu & Rp 5,36 triliun (269 temuan) & tidak ada data (10 temuan) \\
3. Kemendikbud & Rp 3,34 triliun (887 temuan) & Rp 1,35 triliun (670 temuan) \\
4. Kemenkes & Rp 332,86 miliar (282 temuan) & Rp 119,89 miliar (69 temuan) \\
5. Kemen ESDM & Rp 319,86 miliar (68 temuan) & tidak ada data \\
6. Kemenhut & Rp 163,50 miliar (148 temuan) & Rp 9,02 miliar (42 temuan) \\
7. Kemensos & Rp 157,84 miliar (46 temuan) & Rp 1,09 miliar (3 temuan) \\
8. Kemenag & Rp 119,31 miliar (464 temuan) & Rp 42,89 miliar (287 temuan) \\
9. Kemenpora & Rp 115,447 miliar (29 temuan) & Rp 101.86 miliar (17 temuan) \\
10.Kemenkominfo & Rp 102,48 miliar (168 temuan) & Rp 64,58 miliar (119 temuan) \\
\hline
\end{tabular}

Sumber: Data diolah FITRA dari hasil audit BPK terhadap anggaran 2009-2011 
Tabel 2. Data Kriminalitas 2012

\begin{tabular}{lllll}
\hline Jenis kasus & 2011 & 2012 & Peningkatan & Peningkatan $(\%)$ \\
\hline 1. Narkoba & 22.976 & 26.561 & 3.585 & 15,6 \\
2. Pembunuhan & 21.770 & 32.219 & 10.449 & 47,9 \\
3. Miras & 211 & 260 & 49 & 23,2 \\
4. Perampokan & 935 & 1.094 & 159 & 17,0 \\
5. Tawuran & 128 & 330 & 202 & 157,8 \\
6. Pelacuran & 1.676 & 2.298 & 622 & 37,1 \\
7. KDRT & 898 & 1357 & 459 & 51,1 \\
8. Sex bebas & 110.468 & 113.878 & 3.410 & 3,1 \\
\hline
\end{tabular}

Sumber : disarikan dari berbagai sumber.

Dari data kasus korupsi yang terjadi di lembaga dan kementerian Negara dapat diperoleh gambaran betapa akutnya kasus korupsi di Indonesia. Jumlah kasus yang sedemikian besar cerminan, betapa korupsi sebagai sesuatu yang jamak dilakukan oleh penyelenggara negara. Hal ini adalah cerminan telah hilangnya karakter penyelenggara negara, sehingga harapan untuk mewujudkan good government and clean government gagal terwujud. Goal attainment negara telah gagal karena Negara gagal membangun memelihara pola kerja yang jujur dan bersih. Dari survei yang dilakukan oleh transparency.org, sebuah badan independen dari 146 negara, tercatat data 10 besar negara yang dinyatakan sebagai negara terkorup Indonesia berada pada peringkat 5, sementara untuk kawasan Asia Pasifik Indonesia ditempatkan pada peringkat pertama negara terkorup. Penyelenggara negara dan pejabat pemerintah baik pusat maupun daerah yang seharusnya menjadi contoh dalam pelaksanaan good government and clean government, justru banyak yang terlibat kasus korupsi yang berujung terali besi. Kasus korupsi Hambalang, wisma atlet, dana hibah perguruan tinggi telah menyeret banyak politisi yang awalnya gencar mengatakan "tidak" pada korupsi. Mereka yang seharusnya memperhatikan dan memperjuangkan nasib rakyat justru malah rakus makan uang rakyat. DPR sebagai lembaga legislatif yang seharusnya sebagai penjaga ketertiban negara dengan produk hukum yang dihasilkanya, justru menjadi pelopor pelanggar hukum. Lembaga DPR menjadi sarang koruptor yang memperkaya diri atau partainya dengan dengan makan uang negara. Negara telah gagal menjalankan fungsi goal attainmentnya, sehingga negara gagal mewujudkan tata kelola pemerintahan yang bersih yang dapat menyejahterakan rakyatnya.

Krisis karakter terjadi dalam masyarakat seperti yang tergambar pada Tabel 2 di atas, tingginya angka kriminalitas seperti penggunaan narkoba, pembunuhan, perampokan yang dari tahun ketahun jumlah pemakai maupun kasusnya terus bertambah. Masyarakat sebagai pemelihara nilai dan norma tidak berdaya mengendalikan perilaku menyimpang warganya. Perubahan sosial dan budaya dalam masyarakat membawa dampak positif dan negatif. Ketidakmampuan struktur masyarakat menyesuaikan diri dengan perubahan akan mendorong masyarakat bertindak di luar nilai dan norma. Kegagalan masyarakat dalam melakukan integrasi antara nilainilai yang dianut dengan keinginan masyarakat mendorong masyarakat untuk berperilaku menyimpang yang akan berujung pada krisis karakter di masyarakat.

Disfungsi keluarga juga nampak menggejala dalam masyarakat modern. Keluarga sebagai tempat sosialisasi penanaman nilai-nilai karakter pada anak gagal menjalankan perannya, karena banyaknya konflik dalam keluarga itu sendiri. Data akhir tahun 2012 Komisi Nasional Perlindungan Anak (Komnas PA), sebanyak 10.105.230 anak Indonesia menjadi korban pelanggaran pada perlindungan khusus. Angka tersebut dikelompokan pada 10 cluster, yakni kekerasan, anak berhadapan dengan hukum, narkoba, rokok, pembuangan bayi termasuk penelantaran dan penculikan, perdagangan anak, pencandu pornografi dan seks bebas, anak menjadi korban bunuh diri, pernikahan dini, serta pekerja anak (http://sains.kompas.com/-read/ 2012/12/22/13370183/Tahun.2012). Data tersebut sebagai gambaran keluarga sudah meng- 
alami disfungsi sebagai tempat yang nyaman untuk anak tumbuh dan berkembang. Banyaknya konflik dalam keluarga ini membuat anak, secara mental ada sosialisasi yang tidak sempurna sehingga terjadilah penyimpangan-penyimpangan dalam tindakan mereka. Mereka melampiaskan kekecewaanya pada tawuran, seks bebas, narkoba dan bentuk penyimpangan lainya. Berdasarkan data dari KPAI setidaknya 17 remaja tewas dalam tawuran di wilayah Jabodetabek sejak 1 Januari 2012 hingga 26 September 2012. "Jumlahnya meningkat dari 2011 yang sebesar 12 orang tewas. (http://www.kpai.go.id/publikasi-main menu33/artikel/258-tawuran-pelajar-mempri

hatinkanduniapendidikan. html). Banyaknya kasus penyimpangan dalam keluarga ini menunjukkan disfungsi keluarga dalam menjalankan fungsinya sebagai tempat pertama dan utama dalam menanamkan nilai dan norma untuk membentuk anak yang berkarakter dan bermoral tinggi. Keluarga telah gagal mempertahankan pola sebagai peletak dasar nilai-nilai dan norma untuk membekali anak dengan budi pekerti yang baik. Orang tua banyakn yang gagal melakukan adaptasi dengan perubahan pola piker dan budaya anak jaman modern. Ketidak mampuan ini membuat kelaurga tidak mampu membawa dan mengarahkan pola perilaku agar sesuai dengan nilai dan norma. Tingginya angka KDRT, kasus perselingkuhan yang berujung pada perceraian cermin hilangnya goal attainment keluarga itu sendiri yang secara Islam dimaknai untuk mewujudkan keluarga yang sakinah mawadah warahmah.

Banyaknya praktik penyimpangan dalam pengelolaan pendidikan, dikarenakan lembaga pendidikan sudah mulai kehilangan ruhnya sebagai pihak yang paling bertanggung jawab untuk menanamkan nilai-nilai karakter kepada siswa. Pendidikan telah banyak terkontaminasi dan diintervensi oleh kepentingan-kepentingan, baik itu kepentingan pribadi kepala sekolah atau pejabat Dinas Pendidikan maupun kepentingan politik pemerintah daerah. Banyaknya kasus markup nilai, budaya menyontek yang sistemik maupun banyaknya manipulasi dalam pengelolaan keuangan sekolah cermin hilangnya krisis karakter dari para pemangku dunia pendidikan. Perguruan tinggi belum mempunyai university culture, yang tercermin dengan banyaknya kasus plagiarism, rendahnya peng- hargaan akan sebuah karya dan rendahnya integritas mahasiswa. Kemampuan adaptasi (adaptation) manajemen sekolah terhadap perubahan regulasi maupun perilaku perkembangan anak nampak tidak berhasil, sehingga sekolah gagal mempertahankan pola (latency) sebagai tempat menyemai dan menanam utama akan nilai-nilai karakter.

Pers adalah lembaga sosial dan wahana komunikasi massa yang melaksanakan kegiatan jurnalistik meliputi mencari, memperoleh, memiliki, menyimpan, mengolah, dan menyampaikan informasi baik dalam bentuk tulisan, suara, gambar, suara dan gambar, serta data dan grafik maupun dalam bentuk lainnya dengan menggunakan media cetak, media elektronik, dan segala jenis saluran yang tersedia (UU No. 40 tahun 1999, tentang pers). Kebebasan pers yang seharusnya membawa manfaat berupa pencerahan kepada masyarakat terhadap perkembangan dunia lokal dan global justru membawa dampak negatif dalam kehidupan bermasyarakat. Kebebasan pers yang kurang bertanggung jawab, seperti pemberitaan yang tidak memenuhi kode etik jurnalistik, justru malah menimbulkan konflik pihak-pihak yang berkepentingan. Kebebasan pers yang tidak bertanggung jawab juga justru sering kali merugikan narasumber berita itu sendiri. Banyaknya kasus kekerasan, kriminalitas dan budaya sex bebas indikasi adanya peran pers. Pemberitaan tentang kekerasan, criminal ataupun konflik yang terus-menerus membuat masyarakat semakin terbiasa dan permisif dengan budaya kekerasan yang ada dimasyarakat. Tayangan porno aksi dan porno grafi dari mass media, ataupun film dan sinetron yang banyak menayangkan pergaulan bebas, banyak mempengaruhi pola pergaulan remaja yang lebih bermisif sehingga sering terjadi sex bebas di kalangan remaja. Hal ini dimungkinkan karena mandulnya pihak yang berwenang dalam mengendalikan kelalain ini, seperti lembaga penyiaran maupun dewan pers yang kurang maksimal dalam menjalankan fungsinya. Pers telah mengadaptasi perubahan perilaku masyarakat yang salah, sehingga secara goal attainment pers telah kehilangan arah sebagai media pencerah bagi pemikiran masyarakat. Media massa telah gagal mengintegrasikan antara fakta, kebutuhan masyarakat dengan kebutuhan media massa yang terlalu profit oriented. 


\section{Upaya Solusi Krisis Karakter Teori Struktural Fungsional}

Upaya solusi dari krisis karakter harus berangkat dari upaya mengembalikan peran lembaga dan struktur sosial yang ada di dalam masyarakat, untuk tetap berpegang teguh pada nilai dan norma yang dianut masyarakat, sehingga ia mampu mengendalikan adanya penyimpangan nilai dan norma yang dilakukan oleh anggotanya. Upaya solusi dari krisis karakter di Indonesia dapat dilihat dalam lembaga atau struktur masyarakat berikut.

\section{Lembaga Pemerintah}

Komitmen pemerintah untuk menegakkan tata kelola pemerintahan yang bersih harus dibarengi tindakan nyata. Dimulai dengan pemilihan anggota kabinet harus benar-benar dipilih orang-orang yang ahli dan kompeten dalam bidangnya tidak sekedar politik balas budi karena telah partainya telah ikut memenangkan pilpres. Kalau ini terjadi maka pembentukan kabinet tidak lebih dari sekedar politik dagang sapi. Penyelenggaraan tata pemerintahan yang bersih juga dapat dimulai dari proses seleksi anggota PNS maupun TNI dan polri yang bersih dan bebas KKN. Transparansi dan akuntabilitas yang tinggi dalam penerimaan CPNS maupun anggota TNI Polri merupakan langkah awal pembenahan birokrasi. Hal ini untuk menghindari pungutan liar penerimaan CPNS maupun seleksi anggota TNI dan Polri yang mencapai ratusan juta rupiah yang mencerminkan kemandulan lembaga pemerintah dalam mencegah praktik KKN. Transparansi dan akuntabilitas publik harus dikedepankan dalam rangka good government dan clean government.

Perubahan mekanisme dan peraturan tentang pemilihan dan keanggotaan DPR harus ditinjau ulang. Bagaimana agar mekanisme pencalonan dan pemilihan anggota DPR dapat dikemas lebih efisien dan berbiaya murah. Biaya politik yang mahal mendorong permaian politik uang yang mengorbankan demokrasi, karena suara pemilih harus dibayar dengan uang. Hal inilah yang mendorong tingginya biaya politik DPR, termasuk tuntutan gaji yang tinggi fasilitas berbiaya tinggi belum lagi rentan tindak korupsi karena tuntutan high cost politik untuk membiayai partai, memelihara konstituen dan lain seba- gainya. Perlu kesadaran yang tinggi untuk bersikap sebagai negarawan untuk menjadi pejabat pemerintah baik eksekutif, yudikatif, maupun legislatif. Pemilihan aparat penegak hukum harus berdasarkan prestasi dan kompetensi yang dilakukan secara transparan dan independenpent, bukan karena pertimbangan strategi kepentingan kelompok/golongan tertentu saja.

Hal ini untuk menghindari adanya bias kepentingan ketika dihadapkan pada suatu kasus yang dialami oleh pihak-pihak yang telah mempromosikanya. Antara lembaga eksekutif, yudikatif dan legislatif harus mampu bersinergi mengembangkan peran kontrol antarlembaga bersama dengan masyarakat dan mass media sehingga penyimpangan dalam praktik pemerintahan dapat diminimalkan.

\section{Masyarakat}

Masyarakat adalah cermin budaya, tindakan yang dilakukan masyarakat secara umum adalah cermin sekaligus sebagai representasi dari dari nilai dan norma yang dianutnya. Pemeliharaan nilai dan norma adalah tanggung jawab bersama masyarakat yag umumnya dipimpin oleh tokoh-tokoh masyarakat maupun tokoh agama. Komunikasi yang baik antarwarga masyarakat misalnya dengan adanya kumpulan RT dan RW dapat berfungsi untuk mencari solusi permasalahan warga, termasuk di dalamnya untuk mengatasi apabila ada penyimpangan di lingkunganya misalnya perjudian, mabuk-mabukan ataupun pesta narkoba.

Keberadaan lembaga agama berperan penting untuk menanamkan nilai-nilai kepada masyarakat. Pada masyarakat Islam, pengajian yang dilakukan secara intensif, baik untuk bapak-bapak, untuk kaum ibu, maupun pemuda atau yang sifatnya umum dapat berperan efektif untuk mengendalikan masyarakat agar bertindak sesuai dengan nilai dan norma. Masyarakat dengan aktivitas religius yang kuat, akan lebih tertib dan terhindar dari perilaku menyimpang. Untuk itu, peran lembaga agama harus terus didorong sebagai kendali atas penyimpangan dalam masyarakat.

\section{Keluarga}

Keluarga harus memposisikan diri sebagai tempat penanaman nilai-nilai yang pertama dan utama bagi seorang anak. Nafsu materialisme dan semangat eksistensi diri 
yang berlebihan harus dikurangi, agar orang tua punya lebih punya banyak waktu untuk mengasuh dan mendidik anak. Apakah seorang wanita karier workaholic pasti dapat memberikan pengasuhan yang lebih baik buat anak-anaknya? Siapa yang dapat menggantikan peran ibu untuk membimbing dan tempat berbagi cerita anak-anak mereka yang masih dalam masa perkembangan? Kurangnya kasih sayang dan pengasuhan dari orang tua mengakibatkan adanya penurunan karakter anak. Hal ini dikarenakan anak tidak mendapatkan bimbingan dan pendampingan yang cukup untuk membantunya tumbuh manjadi manusia dewasa. Orang tua sebagai model utama seorang anak, maka harus pintar menempatkan diri sebagai sosok yang dijadikan teladan baik tingkah laku ucapan maupun pemikirannya. Keluarga harus mampu memainkan perananya sebagai peletak dasar nilai dan norma sebagai dasar bagi pembentukan karakter anak.

Orang tua harus bisa membangun komunikasi yang efektif dengan anak-anaknya, budaya demokratis dan sikap terbuka penting untuk dikembangkan. Hal ini dimaksudkan agar anak terbiasa terbuka dengan orang tuanya untuk mendiskusikan permasalahan dan hal-hal yang menimbulkan kegelisahan baginya sehingga orang tua bisa bisa memberikan bimbingan yang dibutuhkan. Orang tua harus mengupgrade keilmuanya dalam hal pengasuhan anak. Perubahan jaman berdampak pada perubahan pola pikir dan pola perilaku anak, orang tua tidak bisa mendidik anak hanya dengan mengandalkan pola-pola lama. Ilmu parenting menjadi penting untuk terus diasah, agar orang tua dapat menjalankan pengasuhan, dan pembimbingan sesuai dengan kebutuhan anak.

\section{Lembaga Pendidikan}

Sekolah atau perguruan tinggi sebagai lembaga pendidikan merupakan pengawal utama kebudayaan, harus menanamkan nilainilai luhur melalui pengajaran di kelas dan juga praktik keteladanan penyelenggara pendidikan di sekolah. Praktik keteladanan perilaku oleh semua pemangku praktik pendidikan termasuk juga guru dalam menerapkan nilai kejujuran sportivitas, transparansi, termasuk dalam pengelolaan dana pendidikan harus diutamakan. Penanaman nilai-nilai karakter di dalam lembaga pendidikan dapat dilakukan melalui dua cara: pertama, dengan desaian berbasis kelas, yang berbasis pada relasi guru sebagai pendidik dan siswa sebagai pembelajaran. Kedua, desain pembelajaran yang berbasis kultur sekolah yang mampu membentuk karakter anak didik dengan bantuan pranata sekolah agar nilai tertentu terbentuk dan terbatinkan dalam diri siswa. Pendidikan karakter berbasis kelas berarti dengan upaya mengintegraikan nilai-nilai karakter dalam pembelajaran dengan menanamkan nilai-nilai sesuai dengan topik atau materi yang sedang dipelajari. Pendidikan karakter berbasis kultur sekolah berarti upaya penanaman nilai melalui budaya yang diciptakan di lingkungan sekolah, seperti melalui kantin kejujuran, upacara bendera untuk menanamkan rasa kebangsaan, pendidikan demokrasi di lingkungan sekolah atau melalui pendidikan lngkungan hidup.

Perguruan tinggi perlu untuk menciptakan university culture yang menghargai budaya intelektual, dan budaya ilmiah untuk mengikis perilaku plagiarisme. Penciptaan iklim yang ilmiah yang kompetitif dan memberikan apresiasi yang tinggi terhadap karya ilmiah juga penting untuk mendorong lahirnya karya dan ilmu baru yang bermanfaat bagi masyarakat.

Keterlibatan yang intensif antar berbagai stake holder pendidikan kiranya akan mampu mengeliminasi berbagai penyimpangan pengelolaan pendidikan. Transparansi dan komunikasi yang intensif antar berbagai stake holder pendidikan akan mampu meningkatkan terhadap praktik pengawasan pengelolaan pendidikan sehingga dunia pendidikan dapat diselamatkan dari krisis karakter.

\section{Lembaga Pers}

Pers memegang peranan besar terhadap kehidupan manusia modern, yang selalu dinamis dan penuh perubahan. Derasnya arus informasi masyarakat global harus dikemas dengan apik dan bertanggung jawab sehingga informasi yang disampaikan kepada masyarakat membawa dampak progresif bagi kehidupan masyarakat. Untuk itu lembaga yang berwenang dalam hal ini dewan pers atau komisi penyiaran untuk acara televisi hendaknya mempunyai rule yang jelas dan tegas sehingga berita dan acara yang disampaikan membawa dampak positif kepada masyarakat, bukan justru menimbulkan konflik dan mengikis karakter masyarakat. Sosok pekerja media harus dibekali dengan moralitas yang 
baik, karena karya mereka menjadi konsumsi publik yang akan sangat memengaruhi cara pandang dan perilaku masyarakat secara luas.

Peran serta pemerintah sebagai pengawas sangat diperlukan untuk menjamin dunia pers mampu mengedepankan moralitas dalam menyajikan berita dan tanyangannya kepada masyarakat. Masyarakat sebagai konsumen juga dapat menjalankan fungsinya sebagai controller dengan bersikap kritis terhadap produk pers dan media massa, dan menunjukkan rasa kepedulianya melaporkan kepada pihak yang berwenang bila menjumpai adanya produk pers dan media massa yang menimbulkan keresahan dan goncangan dalam sistem nilai masyarakat.

\section{SIMPULAN}

Karakter adalah hal fundamental yang harus dimiliki suatu bangsa untuk dapat eksis dalam percaturan persaingan global. Struktur masyarakat yang ada suatu negara berfungsi untuk menjaga agar nilai-nilai karakter yang dianut masyarakat agar kehidupan masyarakat berjalan stabil penuh keteraturan. Penyimpangan nilai dan norma yang ada dalam masyarakat akan berujung krisis karakter apabila struktur dalam masyarakat tidak mampu untuk mengendalikannya.

Berbagai kasus pelanggaran nilai dan norma baik yang dilakukan baik oleh penyelenggara negara, anggota masyarakat, media massa, maupun keluarga adalah cermin adanya krisis karakter yang dialami bangsa Indonesia. Struktur yang ada pada lembaga negara, masyarakat maupun keluarga telah gagal menjalankan fungsinya untuk menjaga nilai dan norma dan sebagai pengendali tindakan masyarakat untuk berbuat sesuai dengan nilai dan norma.

Mengembalikan fungsi dan peran struktur yang ada dalam masyarakat adalah cara yang bisa dilakukan agar struktur masyarakat termasuk keluarga mampu menjaga nilai dan norma sehingga mampu menjadi pengendali dari tindakan anggota-anggotanya. Struktur masyarakat yang kuat secara fungsional akan mampu menciptakan kehidupan masyarakat yang stabil dan penuh keteraturan. Adanya tranparansi, akuntabilitas serta fungsi kontrol yang efektif dari berbagai elemen dan struktur masyarakat juga dapat menjadi kendali atas krisis karakter yang terjadi dalam masyarakat.

\section{DAFTAR PUSTAKA}

Craib, I. (1986). Teori-teori sosiologi modern. CV. Rajawali: Jakarta.

Dwiningrum, S. I. A., dkk (2012). Ilmu sosial \& budaya dasar. UNY Press: Yogyakarta.

http://www.kpai.go.id/publikasi-mainmenu33/artikel/258-tawuran-pelajarmemprihatinkan-duniapendidikan.html. Pada 17 Feruari 2012 jam 04.10.

http://www.tempo.co/read/news/2012/08/29/0 78426251/Ribuan-Pejabat-Daerah Terlibat-Kasus-Korupsi.Pada 17 Feruari 2012 jam 04.15.

Poloma, M. M.(2007). Sosiologi kontemporer. Raja Grafindo Persada: Jakarta.

Ritzer, G. \& Douglas, J. G. (2005). Teori sosiologi modern. Prenada Media: Jakarta.

Samani, Muchlas \& Hariyanto (2012). Pendidikan karakter. Remaja Rosdakarya: Bandung.

Undang-Undang Republik Indonesia Nomor 40 tahun 1999 tentang Pers http://www.antaranews.com/berita/318 719/setiap-hari-ada-311-kasus-kdrt. Pada 17 Feruari 2012 jam 04.00

Wibowo, Agus. (2012). Pendidikan karakter. Pustaka Pelajar: Yogyakarta.

Zuchdi, Darmiyati. (2012). Pendidikan karakter. UNY Press: Yogyakarta. 